Article

\title{
Using Microscopic Simulation-Based Analysis to Model Driving Behavior: A Case Study of Khobar-Dammam in Saudi Arabia
}

\author{
Hassan M. Al-Ahmadi ${ }^{\mathbb{D}}$, Arshad Jamal *, Imran Reza, Khaled J. Assi ${ }^{\mathbb{D}}$ and Syed Anees Ahmed \\ Department of Civil Engineering, King Fahd University of Petroleum \& Minerals (KFUPM), \\ Dhahran 31261, Saudi Arabia; ahmadi@kfupm.edu.sa (H.M.A.-A.); ireza@kfupm.edu.sa (I.R.); \\ khaledassi@kfupm.edu.sa (K.J.A.); s_anees42@yahoo.com (S.A.A.) \\ * Correspondence: arshad.jamal@kfupm.edu.sa
}

Received: 24 April 2019; Accepted: 23 May 2019; Published: 28 May 2019

\begin{abstract}
Sustainable transportation systems play a key role in the socio-economic development of a country. Microscopic simulation models are becoming increasingly useful tools in designing, optimizing, and evaluating the sustainability of transportation systems and concerned management strategies. VISSIM, a microscopic traffic simulation software, has gained rapid recognition in the field of traffic simulation. However, default values for different input parameters used during simulation need to be tested to ensure a realistic replication for local traffic conditions. This paper attempts to model driving behavior parameters using the microscopic simulation software VISSIM through a case study in the Khobar-Dammam metropolitan areas in Saudi Arabia. VISSIM default values for different sensitive parameters such as lane change distances, additive and multiplicative parts of desired safety distances, the number of preceding vehicles spotted, amber signal decisions, and minimum headway were identified to be most sensitive and significant parameters to be calibrated to precisely replicate field conditions. The simulation results using default values produced higher link speed, larger queue length, and shorter travel times than those observed in the field. However, measures of effectiveness (MOEs) obtained from calibrated models over desired simulation runs were comparable to those obtained from field surveys. All compared MOEs used to validate the model matched within a range of $5-10 \%$ to the field-observed values.
\end{abstract}

Keywords: transportation systems; sustainability; simulation; VISSIM; calibration and validation

\section{Introduction}

A sustainable transportation system is essential for efficient mobility and accessibility for all road users in a safe and environment-friendly transport mode. Microscopic traffic simulation has emerged as extremely useful tool in recent years for evaluating and optimizing different complex traffic management and control systems. Real-world traffic network dynamics are realistically replicated using these microscopic simulation tools by simulating an individual vehicle's movement through the network. In addition, these tools can assess the sustainability of transport systems by estimating entities such as fuel consumption rates, operational impact, air quality impact, toll revenues, accident risk factors, and so on [1]. The efficiency of emerging technologies like intelligent transportation systems (ITS) can also be evaluated using such simulation tools. Researchers have also used microscopic simulation models to evaluate the safety performance of transportation network due to the recent developments in human behavior modeling [2-5]. The inherent advantage of adopting a simulation tool for evaluating the sustainability of transport systems lies in less cost involvement, and it is safer and faster than field implementation [6]. 
Microscopic traffic simulation models have different independent default parameters to represent traffic control characteristics and traffic control operations. The fundamental component of any microscopic simulation tool is the driver's behavior. Driver's behavior explains how the drivers make decisions in terms of route choice, car following, and lane selection. All drivers' behavior models consist of parameters and their respective default values, allowing users to input values within a specified range for these driving behavior parameters based on local traffic conditions. Since it has been observed that drivers' behavior varies significantly over driving conditions and geographical location, the default values for these parameters rarely matches the local traffic characteristics and traffic conditions for a specific area $[7,8]$. Thus, the default values for such variables need to be adjusted for a realistic replication of the local driving conditions.

\section{Literature Review}

Researchers in recent years have attempted to calibrate (i.e., adjust the model parameters) different microscopic simulation tools for their respective traffic characteristics and driving conditions [9-14]. Most of the driving behaviors in traffic simulation models are determined through sub-models representing car following, gap acceptance, and lane changing behavior [15]. These sub-models are dependent on parameters that encapsulate the relevant attributes of driver behavior. Car following models are represented by the longitudinal interaction among vehicles in a traffic stream. The speed of the following vehicle is considered to be a response to stimuli from the preceding vehicle or vehicles. Gap acceptance models are related to the process where a driver tends to find an acceptable gap in a traffic stream whenever there is a need to cross or merge into the stream. Lane changing model associates an individual driver's ability and intention to change lanes to gain some advantage or avoid incidents [15].

However, the calibration process is not that easy and straightforward, because of the difficulties encountered in measuring microscopic parameters from the field. So instead of measuring microscopic parameters, most of these calibration methods rely on field-measured macroscopic parameters (average link speed, average acceleration/deceleration, average travel time and flow, etc.) as a measures of effectiveness (MOEs) to replicate and calibrate microscopic driving behavior parameters [6]. With an aim to enhance the calibration process, several optimization-based techniques, including simplex-based approaches, gradient searches, and genetic algorithms (GA) have been proposed in recent years [9]. Among these methods, GA is the most widely adopted method because of its computational efficiency and ability to find optimal solutions. Other calibration parameter optimization techniques can be found in Yu et al. [16]. Further, it is essential that model validation should not be confused with model calibration. Model validation, for example, can be used to test the accuracy of the model by comparing the traffic flow data collected from the field with that generated by the model [17]. It is important to recognize four key issues on model validation, which are: establishing the explicit meaning of model validation, collecting the necessary data, quantifying uncertainties, and predicting MOEs [18]. Model validation is associated with the model calibration process directly, since adjustments in calibration are vital for boosting the model's capability to replicate the traffic dynamics observed from the field.

It is vital to select and identify critical calibration parameters, and to determine acceptable ranges for each of the calibration parameters within the microscopic simulation model. Microscopic simulation model software VISSIM has number of such parameters that may be calibrated to replicate realistic field conditions. Some of these parameters include acceleration, desired speed, clearance distance, emergency stopping distance, waiting time before diffusion, lane change distance, standstill distance, minimum headway, etc. However, the calibration of all default software parameters is seldom required. Sensitivity analysis, factorial design, and elementary effects methods have been recently adopted to identify the critical parameters to be calibrated [19]. Sensitivity analysis is performed to reduce the number of candidate calibration parameters and to keep the parameters that significantly affects the 
simulation [3]. Mathew and Radhakrishnan [20] suggested that sensitive parameters can be found by increasing each parameter value by $10 \%$ while keeping other parameter values constant.

From the literature, it was found that only a few studies have been conducted previously that focused on calibration and validation of simulation tools (like CORSIM, PARAMICS, SYNCHRO, etc.) for traffic conditions prevailing across the entire Kingdom of Saudi Arabia [21-23]. However, in this research, more emphasis was given to the method of model calibration and the validation process and comparatively less effort was made on identifying driving behavior parameters solely, which are important in analyzing the cause of different traffic engineering problems, and more importantly, finding general driving patterns that are responsible for accidents. This study contributes to the existing literature by considering a number of key driving behavior parameters, such as lane change distance, minimum headway, number of preceding observed vehicles, etc., which are relatively scarce in present literature in general, and for the Kingdom of Saudi Arabia scenario in particular. The objective of this paper is to obtain the value of a specific set of driving behavior parameters through the process of calibration and validation of a microscopic simulation model for prevailing local traffic conditions in the Khobar-Dammam metropolitan areas (cities in the Eastern Province of Saudi Arabia). A conventional trial and error approach is adopted in order to find the optimal set of driving behavior parameters. The remainder of this paper has been organized into the following sections: first, a brief description of the study sites, data collection, and selection of simulation models and parameters is given. This is followed by the calibration procedure, MOE comparison, and validation of the calibrated model. Finally, research findings and study limitations are summarized, and recommendations regarding potential future research are presented. Figure 1 presents the proposed methodology for the study.

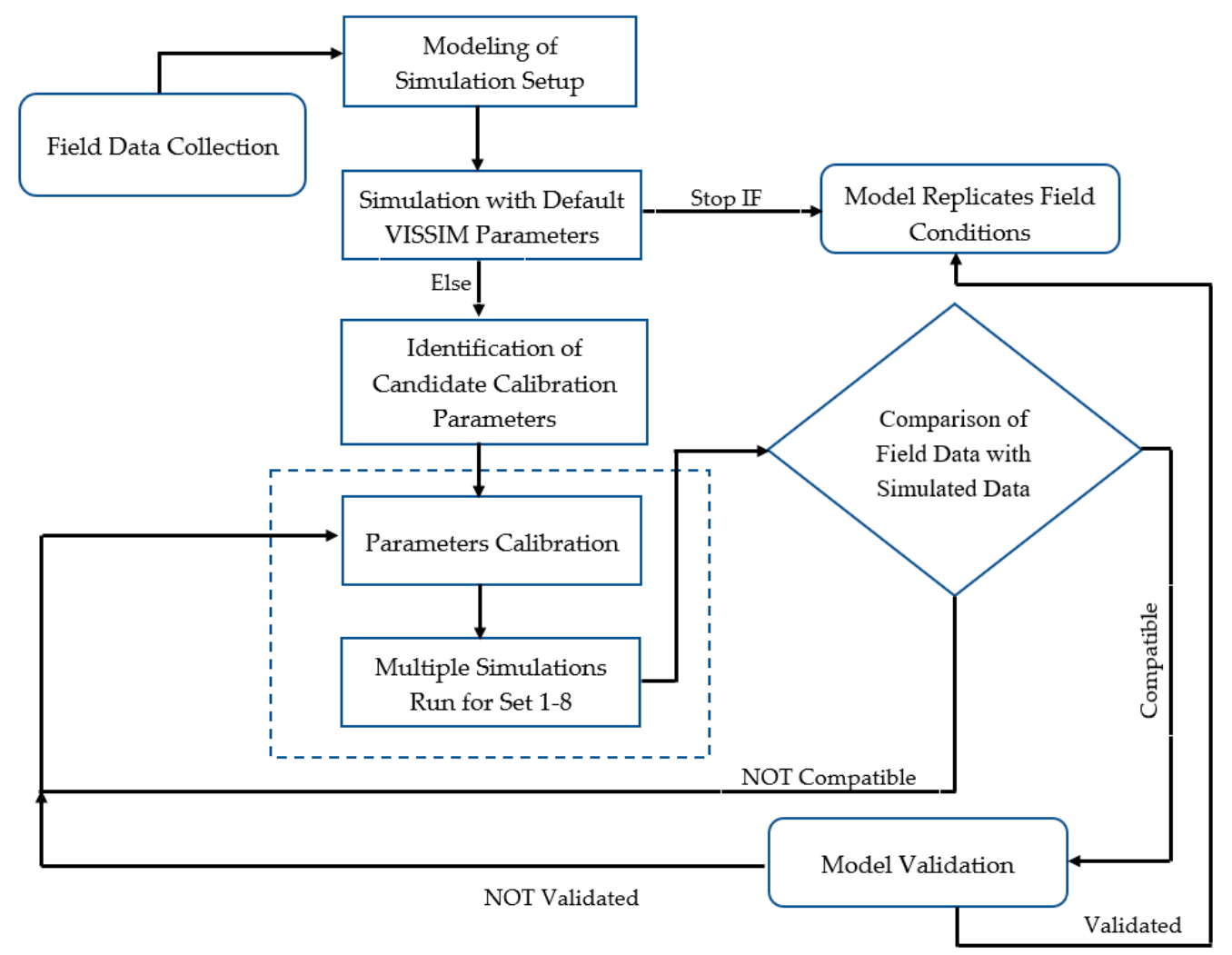

Figure 1. Flow chart for proposed methodology.

\section{Study Area}

The identification of suitable traffic corridor was not an easy task, keeping in mind the complexity of data required for the model formulation. Care was taken in the selection of calibration and validation sites, as it was imperative to ensure that both networks should have comparable cycle lengths in order 
to avoid any inconsistency while collecting data on selected measures of effectiveness (MOEs) such as travel time and queue length from the field. Two such roads, the Custodian of the Two Holy Mosques Road (Dhahran Street) and Prince Mohammad bin Fahd Road, were selected for model calibration and validation, respectively (Figures 2 and 3). Dhahran Street passes through mixed commercial and residential zones. It has four lanes in each direction, consisting of three signalized intersections linking Prince Hamoud Street, Macca Street, and King Abul-Aziz Street. Prince Mohammad bin Fahd Road was used for model validation, and has three lanes in each direction, consisting of three signalized intersections as well, and connects King Abdul Aziz Street, King Saud Street, and King Khaled Street. It is also located in similar mixed residential and commercial setting.

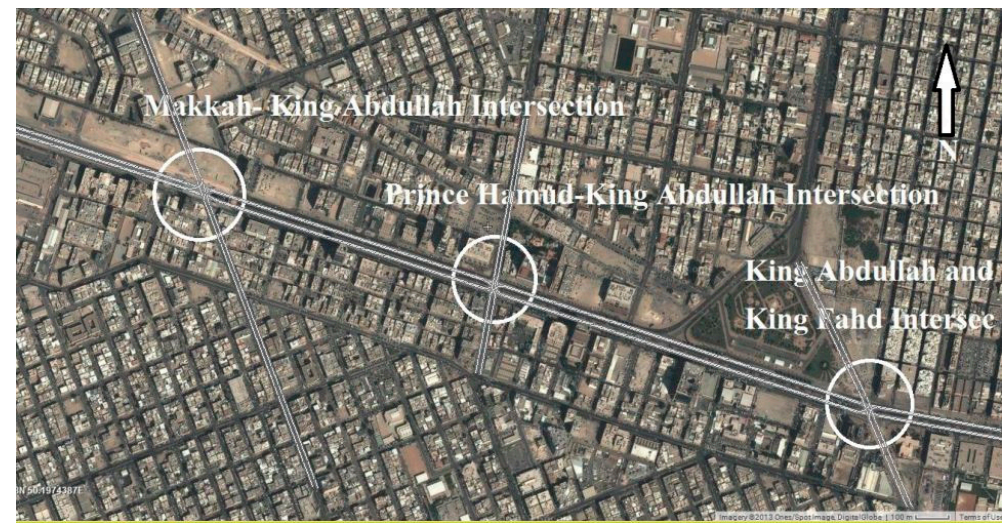

Figure 2. Calibration site: Custodian of Two Holy Mosques (Dhahran Street, Google Map).

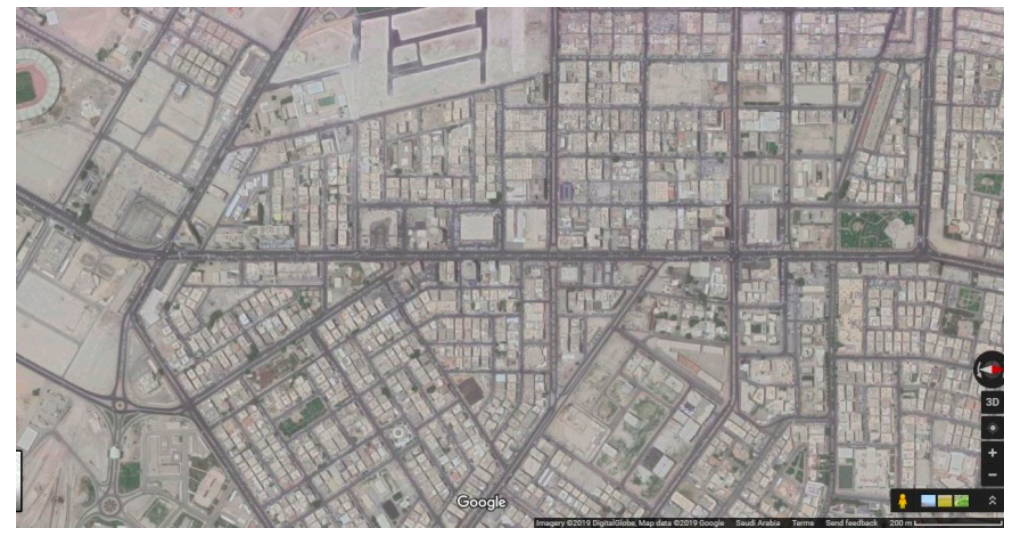

Figure 3. Validation site: Prince Mohammad bin Fahd Road (Google Map).

\section{Data Collection}

Prior to collection of data, it is essential to identify measures of effectiveness (MOEs) appropriate for calibration and validation [24]. It is also essential to identify performance measures and determine and identify both controllable and uncontrollable input parameters. For example, a performance measure could be travel time between two data collection spots in the network. Controllable input parameters during the simulation phase could be minimum headways, waiting time before diffusion, minimum and maximum look-ahead and look-back distances, lane changing distances, and so forth. Uncontrollable input parameters may include information on traffic counts, existing geometry, and so on. Thus, it is necessary to identify all such performance measures before proceeding further for calibration and validation analysis. The next step is to collect data on different performance measures and uncontrollable input parameters from the field.

Two types of data were acquired., For building the simulation model, firstly, basic input data such as traffic volume data, data on turning vehicles' movement, vehicle mix, vehicles' characteristics, network geometry, traffic control systems, and stop signs, were collected. Then, data on several MOEs 
like average link speed, travel time, and average and maximum queue lengths were acquired for model calibration. Prevailing standard procedures were practiced in collecting field data. Since traffic volume is one of the most influential parameters dictating the subsequent operations, traffic volume data were collected with utmost accuracy and care. Manual counting methods were opted for when collecting volume data. Traffic volume data for both calibration (Dhahran Street) and validation (Prince Mohammad bin Fahd Road) networks were collected for a period of $1 \mathrm{~h}$, during the evening peak period from 3:45 pm to 4:45 pm. Data on saturation flow were also obtained at these intersections during the same time period. Signal control data for all the intersections at calibration and validation sites were also collected. The three signalized intersections at Dhahran Street had a cycle length of $135 \mathrm{~s}$. The cycle lengths for two of the intersections linking Prince Mohammad bin Fahd Road with King Saud Street and King Khaled Street were observed to be $180 \mathrm{~s}$, while for third intersection that connects Prince Mohammad bin Fahd Road with King Abdul Aziz Street, the cycle length was 90 s. Field queue lengths were observed and recorded for each intersection for both streets. Trained observers were assigned the task of counting the vehicles in standing or slowly moving queues. Queue length data (both maximum and average) as observed from the field for all the stated intersections are presented later in the analysis section.

\section{Selection of Simulation Model}

A microscopic simulation model software, VISSIM, was used for this study. The model was originally developed in the early 1970s by Rainer Wiedemann at the University of Karlsruhe, Germany. Later in 1993, the firm PTV Transworld AG launched the commercial distribution of the software package. VISSIM is a behavior-based and time step simulation model program. The software has three basic components, including traffic flow models, traffic control models, and a data analysis package. It can be applied to analyze different transportation problems, such as the interaction of different transportation modes, signal prioritization and optimization, freeway operations, traffic management strategies, dynamic traffic assignments, and pedestrian flows, etc. The advantage of using VISSIM over other contemporary software is that the model allows calibration of several parameters that encompass the driver's behavior in order to realistically replicate local traffic conditions. VISSIM is based on a psychophysical car-following model and uses perception thresholds to model driver behavior [25-27]. The enhanced functionalities of VISSIM compared to other simulation tools for analysis of different transportation problems have been demonstrated by a few previous studies [28,29]. VISSIM version 9.0 was used in this study. A summary of available driving behavior parameters is presented in Table 1 for a comparison and justification of the model selection. While other contemporary microsimulation software is mostly calibrated through reaction time and headways, VISSIM offers some additional driving parameters for a better representation of real field conditions.

Table 1. Summary of the literature on driving behavior parameters of different microsimulation models.

\begin{tabular}{|c|c|c|}
\hline Authors & Microsimulation Used & Calibration Parameters \\
\hline Ciuffo et al. [30] & AIMSUN & Drivers' reaction time and speed acceptance \\
\hline Ma et al. [31] & PARAMICS & Mean reaction time and mean headway \\
\hline Mennini et al. [25] & VISSIM & CC1, CC2, CC3, CC4, CC5 (Wiedemen co-efficient) \\
\hline Hourdakis et al. [32] & AIMSUN & $\begin{array}{l}\text { Max. acc. rate, max speed diff., avg. speed, and } 9 \\
\text { othe parameters }\end{array}$ \\
\hline Lee and Ozbay [33] & PARAMICS & Mean reaction time and mean headway \\
\hline Balakrishna et al. [34] & MITSimLab & Car following and lane changing co-efficients \\
\hline Abdalhaq and Baker [35] & SUMO & Deceleration, acceleration, and driver imperfections, etc. \\
\hline Kim et al. [36] & VISSIM & $\begin{array}{l}\text { Number of observed preceding vehicles, look-ahead distance, } \\
\text { average standstill distance, } \\
\text { Additive parameter and a multiplicative parameter and lane } \\
\text { change distance }\end{array}$ \\
\hline
\end{tabular}




\section{Selection of Calibration Parameters}

It is imperative to identify the critical calibration parameters and to determine acceptable ranges for each of the calibration parameters within the microscopic simulation model. There are various parameters that can be calibrated in VISSIM. Asmer et al. [37] reported acceleration, desired speed, and clearance distance, while emergency stopping distance, waiting time before diffusion, lane change distance, standstill distance, minimum headway were used by Park \& Schneeberger [12], and Wiedemann parameters were used by Zhizhou et al. [38] in their studies. However, not all of them are equally significant for calibration. Several sensitivity analyses have been reported in the literature to find out significant calibration parameters. Park and Qi [39] used ANOVA to find the sensitive parameters from a set of eight parameters. Park and Qi [39] also reported the use of a Latin hypercube experimental design along with one-way ANOVA analysis to find sensitive parameters. Factorial design and elementary effects were the other methods used to find sensitive parameters by Punzo \& Ciuffo [40] and Ge \& Menendez [41], respectively. The simulation delay is compared with the delay obtained by using the default value of parameters. If the change in default value affects delay, then the parameter is accounted for as sensitive. Six sensitive parameters were identified by this method in this research. All parameters that were considered for calibration in this study are presented in Table 2.

Table 2. Candidate calibration parameters.

\begin{tabular}{cc}
\hline Parameter Description & VISSIM Default Values \\
\hline Lane change distance $(\mathrm{m})$ & $200 \mathrm{~m}$ \\
No. of preceding observed vehicles & 2 \\
Amber signal decision model & Continuous Check \\
Additive part of safety distance $(\mathrm{m})$ & 2 \\
Multiplicative Part of safety distance $(\mathrm{m})$ & 3 \\
Minimum headway $(\mathrm{s})$ & 0.5 \\
\hline
\end{tabular}

The lane change distance parameter specifies the distance at which a vehicle attempts to leave a particular lane or change lanes. To model drivers' behavior while driving, the lane change distance parameter is frequently used along with the emergency stopping distance parameter. The VISSIM default value for the lane change distance parameter is $200 \mathrm{~m}$. Acceptable ranges for lane change distance parameters were 150 to $300 \mathrm{~m}$ for this study. Values in this range can be assumed to ensure a safe practical distance for a vehicle involved in lane change maneuver. Values that are too small would lead to undesirable emergency stopping conditions.

The number of preceding observed vehicles parameter determines that how well a vehicle in the network can predict and thus react to the movement of other vehicles in the stream. The VISSIM default value for this parameter is two vehicles. A range of two to four vehicles for this variable was considered in this study.

The amber signal decision parameter defines vehicle behavior as it approaches a signal control displaying an amber light. The default indication for this variable in VISSIM is called continuous check. "Continuous check" and "one decision" are the options for this variable in VISSIM. Drivers expect the amber light to remain amber for at least $2 \mathrm{~s}$ in continuous check and decide continuously at each time step if it is safe to proceed. In one decision, the software estimates the probability of a vehicle stopping at amber light. For this study, simulations with both continuous check and one decision were run in conjunction with variation in other parameters.

The additive and the multiplicative parts of the desired safety distances in the car following model (Wiedemann, [26]) determine the saturation flow rate for VISSIM. Higher values for these 
two parameters mean more distance between vehicles, and hence lower roadway capacity. The safe distance between two vehicles is given as [26]:

$$
d_{\text {safe }}=d_{1}+\left(a_{1}+a_{2} \times z\right) \sqrt{v}
$$

where $v$ is the vehicle speed $(\mathrm{m} / \mathrm{s})$ and $d_{1}$ is the average still stand distance indicating the mean distance desired between the stopped vehicles $(\mathrm{m}) . d_{1}$ has a VISSIM default value of $2.0 \mathrm{~m}$. Coefficients $\left(a_{1}\right.$ and $\left.a_{2}\right)$ influence the desired safe distance. The additive part of safety distance $\left(a_{1}\right)$ has a VISSIM default value of 2.0. A value of 2.25 was used in this study. A slight modification was made to this parameter, since the saturation flow rate values observed from the field (1925 vphpl) and those obtained from VISSIM by default (2050 vphpl) were comparable. The multiplicative part of the desired safety distance $\left(a_{2}\right)$ has a VISSIM default value of 3.0. A value of 3.25 for this parameter was used in this study for the reasons stated above, in combination with variation in other parameters.

The minimum headway distance is defined as the minimum distance to the vehicle in front that must be available for a desired lane change. The default value is $0.5 \mathrm{~m}$. The default value appeared to be too small and unrealistic based on field experience, thus a larger value were assumed to be more reasonable.

\section{Network Coding in VISSIM and Model Verification}

For accurate simulations of traffic operations, the modeled infrastructure network needs to be simulated to some scale. Thus, to trace a network precisely in VISSIM, a base map in a bit map format was imported. Based on infrastructure maps and road geometry, study networks were built. A series of links and connectors were used for creating a street network in VISSIM. The proportion of traffic composition was classified as $100 \%$ of passenger cars, since no trucks were observed during the observation period. Traffic volume data from the field, like vehicles' turning movements at intersections and input flow rates, were collected. The first $15 \mathrm{~min}$ during simulation were devoted to model initialization. In order to make sure that the coded VISSIM network replicated the actual field conditions, numerous verifications runs involving examination of the coded networks were initiated. These verification runs unveil various network coding errors, like excessive speeds around corners, lack of right turns on red, and lack of connection between links and these errors were then fixed accordingly. To ensure that the model is functioning as planned, a series of simulation runs were conducted. Ten simulation runs were performed initially, and thereafter, the required number of simulation runs based on mean and standard deviation criteria for specific performance measures were determined, as proposed by researchers from the University of California [42].

\section{Calibration and Validation of VISSIM}

\subsection{Calibration Procedure}

Candidate calibration parameters were adjusted over a number of iterations within specified ranges until the selected performance measures (travel time, travel speed, and queue length) agreed with specifications set by Caltrans, as reported in Table 3. Some other currently in practice "Transportation System Simulation Manual Frameworks", used in different state levels in the USA, were checked to incorporate important issues for VISSIM microsimulation [43-45]. Simulating the network with VISSIM default values for calibration parameters as presented in Table 2, it was revealed that, except for the average queue length, which was conforming to validation criteria, no other performance measures agreed with the field observed MOEs. Thus, calibration of these parameters was considered. Values for candidate calibration parameters over several iterations and multiple simulation runs for the present study are shown in Table 4. 
Table 3. Calibration and validation guidelines adopted for the present study [46].

\begin{tabular}{cccc}
\hline Parameters & Description & Validation Benchmark \\
\hline Average travel speed & $\begin{array}{c}\text { Standard deviation for individual links is within } \\
\text { simulated average travel speed and floating car } \\
\text { average travel speed }\end{array}$ & Within 1 Standard Deviation (SD) \\
Average travel time & $\begin{array}{c}\text { Standard deviation for series of links is within } \\
\text { simulated average travel time and floating car } \\
\text { average travel time }\end{array}$ & Within 1 Standard Deviation (SD) \\
Maximum and average queue length & Percent difference in simulated and observed & 80-120\% of actual observed value \\
\hline
\end{tabular}


Table 4. Set of candidate calibration parameters over simulation runs.

\begin{tabular}{|c|c|c|c|c|c|c|c|c|c|}
\hline \multirow{2}{*}{ Parameters } & \multirow{2}{*}{$\begin{array}{l}\text { Parameter Values } \\
\text { VISSIM Default }\end{array}$} & \multicolumn{8}{|c|}{ Calibrated Parameter Values } \\
\hline & & Set\#1 & Set\#2 & Set\#3 & Set\#4 & Set\#5 & Set\#6 & Set\#7 & Set\#8 \\
\hline Lane change distance $(m)$ & 200 & 300 & 300 & 300 & 250 & 250 & 250 & 200 & $200 *$ \\
\hline $\begin{array}{l}\text { No. of preceding } \\
\text { Observed vehicles }\end{array}$ & 2 & 2.25 & 2.50 & 2.75 & 3.0 & 3.5 & 3.5 & 3.75 & $4^{*}$ \\
\hline $\begin{array}{l}\text { Additive part of } \\
\text { safety- distance }\end{array}$ & 2 & 2.10 & 2.10 & 2.15 & 2.20 & 2.20 & 2.25 & 2.25 & $2.25^{*}$ \\
\hline $\begin{array}{l}\text { Multiplicative part of } \\
\text { safety distance }\end{array}$ & 3 & 3.15 & 3.15 & 3.15 & 3.20 & 3.25 & 3.25 & 3.25 & $3.25 *$ \\
\hline $\begin{array}{l}\text { Minimum headway } \\
\text { Amber signal decision model }\end{array}$ & $\begin{array}{l}0.5 \\
\text { Continuous check }\end{array}$ & $\begin{array}{c}1.0 \\
\text { One decision }\end{array}$ & $\begin{array}{c}1.0 \\
\text { One decision }\end{array}$ & $\begin{array}{l}1.0 \\
\text { Continuous check }\end{array}$ & $\begin{array}{c}1.5 \\
\text { One decision }\end{array}$ & $\begin{array}{l}1.5 \\
\text { Continuous check }\end{array}$ & $\begin{array}{l}1.5 \\
\text { Continuous check }\end{array}$ & $\begin{array}{c}1.75 \\
\text { One decision }\end{array}$ & $\begin{array}{c}1.75 \\
\text { Continuous check * }\end{array}$ \\
\hline
\end{tabular}

* indicates candidates' parameters set that yielded MOEs satisfying the Caltrans' specifications. 


\subsection{Results and Discussion}

MOEs like travel time, travel speed, and average and maximum queue lengths were compared for values of these performance measures as observed from the field with those obtained from VISSIM default values and for different set/combination of calibration variables, as shown in Table 4. It was noted that the Set 8 calibration parameters yielded the values for these performance measures that were in close agreement with field-observed MOEs and satisfied the criteria set by Caltrans (Table 3). A comparison of MOEs obtained from the field to those, yielded by VISSIM default values and those given by adjusting the candidate calibration parameters (Sets 1-8) have been summarized in Tables 5-8. 
Table 5. Average travel time from field, VISSIM default values, and candidate calibrated parameters.

\begin{tabular}{|c|c|c|c|c|c|c|c|c|c|c|c|c|}
\hline \multirow[t]{2}{*}{ Route } & \multirow[t]{2}{*}{ Distance (m) } & \multirow[t]{2}{*}{ Field Values } & \multirow[t]{2}{*}{ SD } & \multirow{2}{*}{$\begin{array}{l}\text { VISSIM Default } \\
\text { (within } 1 \text { SD) }\end{array}$} & \multicolumn{8}{|c|}{$\begin{array}{c}\text { Calibrated Travel Time (s) } \\
\text { (All Sets are within } 1 \text { SD Range) }\end{array}$} \\
\hline & & & & & Set\#1 & Set\#2 & Set\#3 & Set\#4 & Set\#5 & Set\#6 & Set\#7 & Set\#8 \\
\hline $\begin{array}{l}\text { Hamoud St. Int. to } \\
\text { Macca St. Int. }\end{array}$ & 750 & 55 & 3.79 & $\begin{array}{l}49.57 \\
\text { (NO) }\end{array}$ & $\begin{array}{l}50.86 \\
\text { (NO) }\end{array}$ & $\begin{array}{l}49.48 \\
\text { (NO) }\end{array}$ & $\begin{array}{l}49.49 \\
\text { (NO) }\end{array}$ & $\begin{array}{l}49.86 \\
\text { (NO) }\end{array}$ & $\begin{array}{l}49.94 \\
\text { (NO) }\end{array}$ & $\begin{array}{l}50.9 \\
\text { (NO) }\end{array}$ & $\begin{array}{l}51.13 \\
\text { (NO) }\end{array}$ & $\begin{array}{l}51.2 \\
\text { (YES) }\end{array}$ \\
\hline $\begin{array}{l}\text { Hamoud St. Int. to } \\
\text { Abdul Aziz St. Int. }\end{array}$ & 985 & 68 & 4.77 & $\begin{array}{l}62.21 \\
(\mathrm{NO})\end{array}$ & $\begin{array}{l}62.42 \\
\text { (NO) }\end{array}$ & $\begin{array}{l}61.7 \\
(\mathrm{NO})\end{array}$ & $\begin{array}{l}61.8 \\
\text { (NO) }\end{array}$ & $\begin{array}{l}62.48 \\
\text { (NO) }\end{array}$ & $\begin{array}{l}62.44 \\
(\mathrm{NO})\end{array}$ & $\begin{array}{l}62.55 \\
(\mathrm{NO})\end{array}$ & $\begin{array}{l}63.01 \\
(\mathrm{NO})\end{array}$ & $\begin{array}{l}63.4 \\
\text { (YES) }\end{array}$ \\
\hline $\begin{array}{l}\text { Macca St. Int. to } \\
\text { Hamoud St. Int. }\end{array}$ & 735 & 59 & 4.56 & $\begin{array}{l}54.12 \\
\text { (NO) }\end{array}$ & $\begin{array}{l}54.9 \\
\text { (YES) }\end{array}$ & $\begin{array}{l}53.88 \\
(\mathrm{NO})\end{array}$ & $\begin{array}{l}54.99 \\
\text { (YES) }\end{array}$ & $\begin{array}{l}54.20 \\
\text { (NO) }\end{array}$ & $\begin{array}{c}55 \\
\text { (YES) }\end{array}$ & $\begin{array}{l}55.29 \\
\text { (YES) }\end{array}$ & $\begin{array}{l}55.44 \\
\text { (YES) }\end{array}$ & $\begin{array}{l}56.1 \\
\text { (YES) }\end{array}$ \\
\hline $\begin{array}{l}\text { Macca St. Int. to } \\
\text { Ab. Aziz St. Int. }\end{array}$ & 1873.5 & 188 & 4.69 & $\begin{array}{l}183 \\
\text { (NO) }\end{array}$ & $\begin{array}{l}182.8 \\
\text { (NO) }\end{array}$ & $\begin{array}{l}181.6 \\
\text { (NO) }\end{array}$ & $\begin{array}{l}182.9 \\
\text { (NO) }\end{array}$ & $\begin{array}{l}182.37 \\
(\mathrm{NO})\end{array}$ & $\begin{array}{l}183.9 \\
\text { (YES) }\end{array}$ & $\begin{array}{l}184.5 \\
\text { (YES) }\end{array}$ & $\begin{array}{l}183.9 \\
\text { (YES) }\end{array}$ & $\begin{array}{l}185 \\
\text { (YES) }\end{array}$ \\
\hline $\begin{array}{l}\text { Ab. Aziz St. Int. to } \\
\text { Macca St. Int. }\end{array}$ & 1898.2 & 168 & 5.02 & $\begin{array}{l}162.16 \\
\text { (NO) }\end{array}$ & $\begin{array}{l}164.3 \\
\text { (YES) }\end{array}$ & $\begin{array}{l}162.7 \\
\text { (NO) }\end{array}$ & $\begin{array}{l}162.7 \\
\text { (NO) }\end{array}$ & $\begin{array}{l}162.70 \\
\text { (NO) }\end{array}$ & $\begin{array}{l}162.9 \\
\text { (NO) }\end{array}$ & $\begin{array}{l}164.4 \\
\text { (YES) }\end{array}$ & $\begin{array}{l}164.4 \\
\text { (YES) }\end{array}$ & $\begin{array}{l}165 \\
((\mathrm{YES}\end{array}$ \\
\hline $\begin{array}{l}\text { Abdul Aziz St. Int. } \\
\text { to Hamoud St. Int. }\end{array}$ & 1000 & 73 & 3.74 & $\begin{array}{l}68.78 \\
(\mathrm{NO})\end{array}$ & $\begin{array}{l}69.87 \\
\text { (YES) }\end{array}$ & $\begin{array}{l}68.97 \\
(\mathrm{NO})\end{array}$ & $\begin{array}{c}69 \\
(\mathrm{NO})\end{array}$ & $\begin{array}{l}68.94 \\
(\mathrm{NO})\end{array}$ & $\begin{array}{c}69 \\
(\mathrm{NO})\end{array}$ & $\begin{array}{l}69.79 \\
\text { (YES) }\end{array}$ & $\begin{array}{l}69.85 \\
\text { (YES) }\end{array}$ & $\begin{array}{l}69.8 \\
\text { (YES) }\end{array}$ \\
\hline
\end{tabular}

St. indicates "street" and Int. "intersection".

Table 6. Average travel speed from field, VISSIM default values, and candidate calibrated parameters.

\begin{tabular}{|c|c|c|c|c|c|c|c|c|c|c|c|c|}
\hline \multirow[t]{2}{*}{ Route } & \multirow[t]{2}{*}{ Distance (m) } & \multirow[t]{2}{*}{ Field Values } & \multirow[t]{2}{*}{ SD } & \multirow{2}{*}{$\begin{array}{l}\text { VISSIM Default } \\
\text { (within 1 SD) }\end{array}$} & \multicolumn{8}{|c|}{$\begin{array}{l}\text { Calibrated Average Speed }(\mathrm{km} / \mathrm{h}) \\
\text { (All sets are within } 1 \text { SD range) }\end{array}$} \\
\hline & & & & & Set\#1 & Set\#2 & Set\#3 & Set\#4 & Set\#5 & Set\#6 & Set\#7 & Set\#8 \\
\hline $\begin{array}{l}\text { Macca St. Int. to } \\
\text { Hamoud St. Int. }\end{array}$ & 735 & 46.2 & 2.93 & $\begin{array}{l}50.21 \\
(\mathrm{NO})\end{array}$ & $\begin{array}{l}49.48 \\
(\mathrm{NO})\end{array}$ & $\begin{array}{l}50.39 \\
(\mathrm{NO})\end{array}$ & $\begin{array}{l}49.59 \\
(\mathrm{NO})\end{array}$ & $\begin{array}{l}50.14 \\
(\mathrm{NO})\end{array}$ & $\begin{array}{l}49.6 \\
(\mathrm{NO})\end{array}$ & $\begin{array}{l}48.83 \\
\text { (YES) }\end{array}$ & $\begin{array}{l}49.14 \\
(\mathrm{NO})\end{array}$ & $\begin{array}{l}48.67 \\
\text { (YES) }\end{array}$ \\
\hline $\begin{array}{l}\text { Abdul-Aziz St. Int. } \\
\text { to Hamoud St Int }\end{array}$ & 1000 & 50.15 & 2.4 & $\begin{array}{l}52.73 \\
(\mathrm{NO})\end{array}$ & $\begin{array}{l}51.92 \\
\text { (YES) }\end{array}$ & $\begin{array}{l}52.55 \\
(\mathrm{NO})\end{array}$ & $\begin{array}{l}52.54 \\
\text { (YES) }\end{array}$ & $\begin{array}{l}52.55 \\
\text { (YES) }\end{array}$ & $\begin{array}{l}52.5 \\
\text { (YES) }\end{array}$ & $\begin{array}{l}51.98 \\
\text { (YES) }\end{array}$ & $\begin{array}{l}51.93 \\
\text { (YES) }\end{array}$ & $\begin{array}{l}51.95 \\
\text { (YES) }\end{array}$ \\
\hline $\begin{array}{l}\text { Hamoud St. Int. to } \\
\text { Abdul-Aziz St. Int. }\end{array}$ & 985 & 52.15 & 3.06 & $\begin{array}{l}56.09 \\
\text { (NO) }\end{array}$ & $\begin{array}{l}55.87 \\
\text { (NO) }\end{array}$ & $\begin{array}{l}56.44 \\
\text { (NO) }\end{array}$ & $\begin{array}{l}56.42 \\
\text { (NO) }\end{array}$ & $\begin{array}{l}55.81 \\
\text { (NO) }\end{array}$ & $\begin{array}{l}55.8 \\
\text { (NO) }\end{array}$ & $\begin{array}{l}55.76 \\
(\mathrm{NO})\end{array}$ & $\begin{array}{l}55.46 \\
\text { (NO) }\end{array}$ & $\begin{array}{l}55.14 \\
\text { (YES) }\end{array}$ \\
\hline $\begin{array}{l}\text { Hamoud St. Int. to } \\
\text { Macca St. Int. }\end{array}$ & 750 & 57.45 & 2.66 & $\begin{array}{l}54.51 \\
(\mathrm{NO})\end{array}$ & $\begin{array}{l}53.46 \\
(\mathrm{NO})\end{array}$ & $\begin{array}{l}54.61 \\
(\mathrm{NO})\end{array}$ & $\begin{array}{l}54.62 \\
(\mathrm{NO})\end{array}$ & $\begin{array}{l}54.24 \\
(\mathrm{NO})\end{array}$ & $\begin{array}{l}54.2 \\
(\mathrm{NO})\end{array}$ & $\begin{array}{l}53.38 \\
(\mathrm{NO})\end{array}$ & $\begin{array}{l}53.12 \\
(\mathrm{NO})\end{array}$ & $\begin{array}{c}53.1 \\
(\text { YES }\end{array}$ \\
\hline
\end{tabular}

St. indicates "street" and Int. "intersection". 
Table 7. Average queue length from field, VISSIM default values. and candidate calibrated parameters.

\begin{tabular}{|c|c|c|c|c|c|c|c|c|c|c|c|c|c|c|c|c|c|c|c|c|}
\hline \multirow{3}{*}{ Intersection } & \multirow{3}{*}{$\begin{array}{l}\text { Approach } \\
\text { From }\end{array}$} & \multirow{3}{*}{$\begin{array}{c}\text { Queue } \\
\text { Length } \\
\text { Field (m) }\end{array}$} & \multicolumn{2}{|c|}{$\begin{array}{c}\text { Queue Length } \\
\text { VISSIM Default (m) }\end{array}$} & \multicolumn{16}{|c|}{$\begin{array}{l}\text { Calibrated Maximum Queue Length (m) } \\
\text { (\% Variance is within the Range of 80-120\% of Field Value) }\end{array}$} \\
\hline & & & \multirow{2}{*}{$\mathrm{QL}$} & \multirow{2}{*}{$\%$ Var } & \multicolumn{2}{|c|}{ Set\#1 } & \multicolumn{2}{|c|}{ Set\#2 } & \multicolumn{2}{|c|}{ Set\#3 } & \multicolumn{2}{|c|}{ Set\#4 } & \multicolumn{2}{|c|}{ Set\#5 } & \multicolumn{2}{|c|}{ Set\#6 } & \multicolumn{2}{|c|}{ Set\#7 } & \multicolumn{2}{|c|}{ Set\#8 } \\
\hline & & & & & $\mathrm{QL}$ & $\%$ Var & $\mathrm{QL}$ & $\begin{array}{l}\% \\
\text { Var }\end{array}$ & QL & $\%$ Var & $\mathrm{QL}$ & $\%$ Var & $\mathrm{QL}$ & $\%$ Var & $\mathrm{QL}$ & $\%$ Var & QL & $\%$ Var & QL & $\%$ Var \\
\hline Abdul Aziz St. Int. & Dhahran & 39.2 & 40.8 & $\begin{array}{l}-4.1 \\
(\text { YES) }\end{array}$ & 40.1 & $\begin{array}{l}-2.3 \\
(\mathrm{YES})\end{array}$ & 41.1 & $\begin{array}{l}-4.8 \\
(\mathrm{YES})\end{array}$ & 41.5 & $\begin{array}{c}-5.9 \\
(\mathrm{YES})\end{array}$ & 40.5 & $\begin{array}{l}-3.3 \\
(\mathrm{YES})\end{array}$ & 40.9 & $\begin{array}{l}-4.3 \\
(\text { YES })\end{array}$ & 40.7 & $\begin{array}{l}-3.8 \\
(\mathrm{YES})\end{array}$ & 39.8 & $\begin{array}{l}-1.5 \\
(\mathrm{YES})\end{array}$ & 39.9 & $\begin{array}{l}-1.8 \\
\text { (YES) }\end{array}$ \\
\hline Abdul Aziz St. Int. & Khobar & 32.7 & 27.5 & $\begin{array}{l}15.9 \\
(\text { YES }\end{array}$ & 27.6 & $\begin{array}{l}15.6 \\
(\mathrm{YES})\end{array}$ & 27.6 & $\begin{array}{l}15.6 \\
(\mathrm{YES})\end{array}$ & 28.1 & $\begin{array}{l}14.1 \\
(\mathrm{YES})\end{array}$ & 27.8 & $\begin{array}{l}15.0 \\
\text { (YES) }\end{array}$ & 28.4 & $\begin{array}{l}13.2 \\
(\mathrm{YES})\end{array}$ & 27.9 & $\begin{array}{l}14.7 \\
\text { (YES) }\end{array}$ & 27.6 & $\begin{array}{l}15.6 \\
\text { (YES) }\end{array}$ & 28 & $\begin{array}{l}14.3 \\
\text { (YES) }\end{array}$ \\
\hline Hamoud St. Int. & Dhahran & 52.7 & 58.8 & $\begin{array}{l}-11.6 \\
(\mathrm{NO})\end{array}$ & 57.3 & $\begin{array}{l}-8.7 \\
(\mathrm{NO})\end{array}$ & 58.4 & $\begin{array}{l}-10.9 \\
(\mathrm{NO})\end{array}$ & 60 & $\begin{array}{l}-13.9 \\
(\mathrm{NO})\end{array}$ & 58.4 & $\begin{array}{l}-10.8 \\
(\mathrm{NO})\end{array}$ & 60 & $\begin{array}{l}-13.9 \\
(\mathrm{NO})\end{array}$ & 58.8 & $\begin{array}{l}-11.6 \\
(\mathrm{NO})\end{array}$ & 57.9 & $\begin{array}{l}-9.9 \\
(\mathrm{NO})\end{array}$ & 58.8 & $\begin{array}{l}-11.6 \\
\text { (YES) }\end{array}$ \\
\hline Hamoud St. Int. & Khobar & 31.5 & 33.8 & $\begin{array}{l}-7.3 \\
(\mathrm{NO})\end{array}$ & 32.9 & $\begin{array}{l}-4.4 \\
(\mathrm{YES})\end{array}$ & 34.2 & $\begin{array}{l}-8.6 \\
(\mathrm{YES})\end{array}$ & 34.4 & $\begin{array}{l}-9.2 \\
(\mathrm{YES})\end{array}$ & 34.2 & $\begin{array}{l}-8.6 \\
\text { (YES) }\end{array}$ & 34.2 & $\begin{array}{c}-8.6 \\
\text { (YES) }\end{array}$ & 33 & $\begin{array}{l}-4.8 \\
\text { (YES) }\end{array}$ & 32.7 & $\begin{array}{l}-3.8 \\
\text { (YES) }\end{array}$ & 32.7 & $\begin{array}{l}-3.8 \\
\text { (YES) }\end{array}$ \\
\hline Macca St. Int. & Dhahran & 55.9 & 51.7 & $\begin{array}{c}7.5 \\
\text { (YES) }\end{array}$ & 53 & $\begin{array}{c}5.2 \\
\text { (NO) }\end{array}$ & 53.4 & $\begin{array}{c}4.5 \\
\text { (YES) }\end{array}$ & 55.1 & $\begin{array}{c}1.4 \\
\text { (YES) }\end{array}$ & 53.5 & $\begin{array}{c}4.3 \\
\text { (YES) }\end{array}$ & 55.4 & $\begin{array}{c}0.9 \\
\text { (YES) }\end{array}$ & 54.6 & $\begin{array}{c}2.3 \\
\text { (YES) }\end{array}$ & 53.1 & $\begin{array}{c}5.0 \\
\text { (YES) }\end{array}$ & 54.7 & $\begin{array}{c}2.1 \\
\text { (YES) }\end{array}$ \\
\hline Macca St. Int. & Khobar & 21.2 & 23.2 & $\begin{array}{l}-9.4 \\
(\mathrm{NO})\end{array}$ & 22 & $\begin{array}{l}-3.8 \\
(\mathrm{NO})\end{array}$ & 23.5 & $\begin{array}{l}-10.9 \\
\text { (NO) }\end{array}$ & 23.6 & $\begin{array}{l}-11.3 \\
\text { (NO) }\end{array}$ & 23.2 & $\begin{array}{l}-9.4 \\
\text { (YES) }\end{array}$ & 23.2 & $\begin{array}{c}-9.4 \\
\text { (YES) }\end{array}$ & 22.1 & $\begin{array}{l}-4.2 \\
\text { (YES) }\end{array}$ & 21.8 & $\begin{array}{l}-2.8 \\
\text { (YES) }\end{array}$ & 21.7 & $\begin{array}{l}-2.4 \\
\text { (YES) }\end{array}$ \\
\hline
\end{tabular}

Table 8. Maximum queue length from field, VISSIM default values, and candidate calibrated parameters.

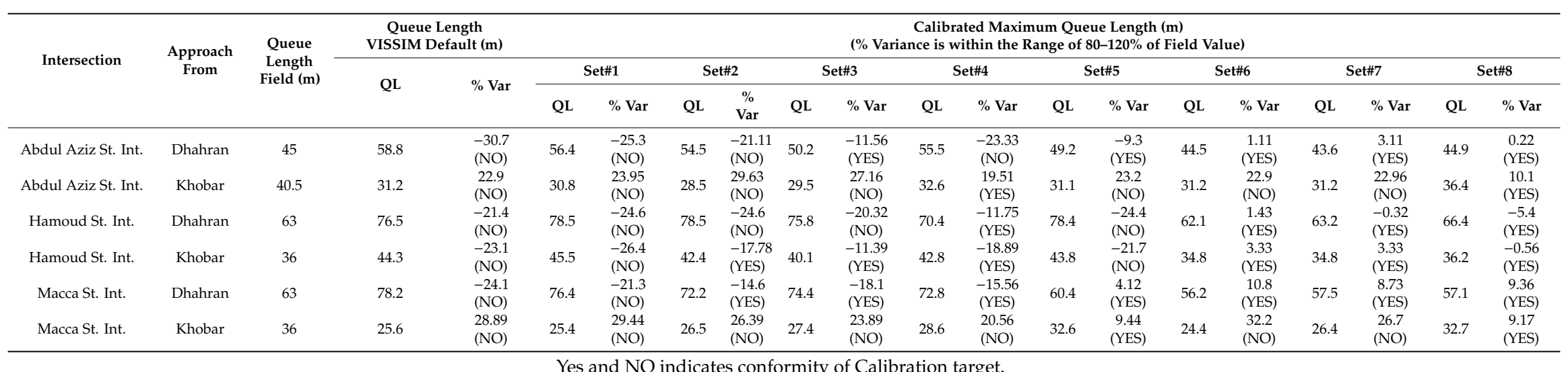


Set 8 parameters were identified as best parameter set, since these parameters yielded performance measures satisfying the stated criteria. Average travel time, average travel speed, and average and maximum queue lengths obtained using Set 8 parameters were close replications of the MOEs observed from the field. Although parameter Set 7 and parameter Set 8 yielded comparable results, parameter Set 8 was chosen since it resulted in more realistic animations. The next step was to validate the calibrated parameter set with new data.

\subsection{Model Validation}

Prince Mohammad bin Fahd Road, connecting to King Saud Street, King Abdul-Aziz Street, and King Khaled Street, was used for validation analysis. Data on MOEs like average link speed, average travel time, and average and maximum queue length were collected. The MOEs observed from the field were compared to a distribution of 50 simulation runs in VISSIM. Set 8's calibrated parameters were identified as most feasible and were used for simulation analysis. Validation analysis results are presented in Figures 4 and 5.

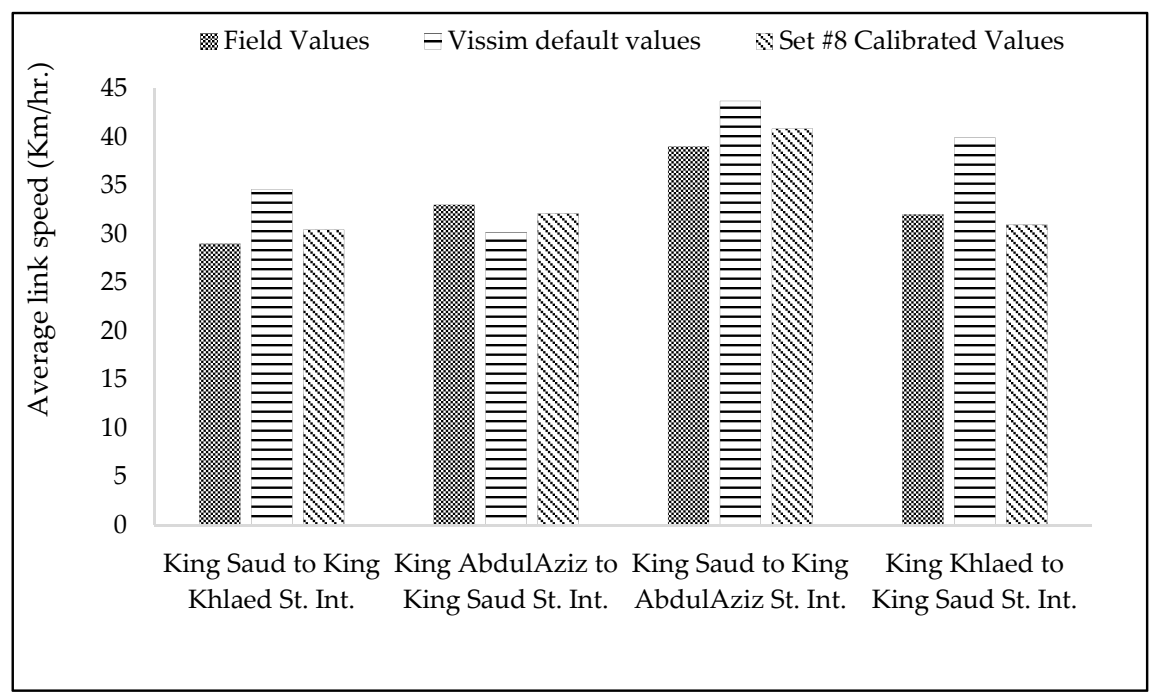

(a) Average link speed comparison.

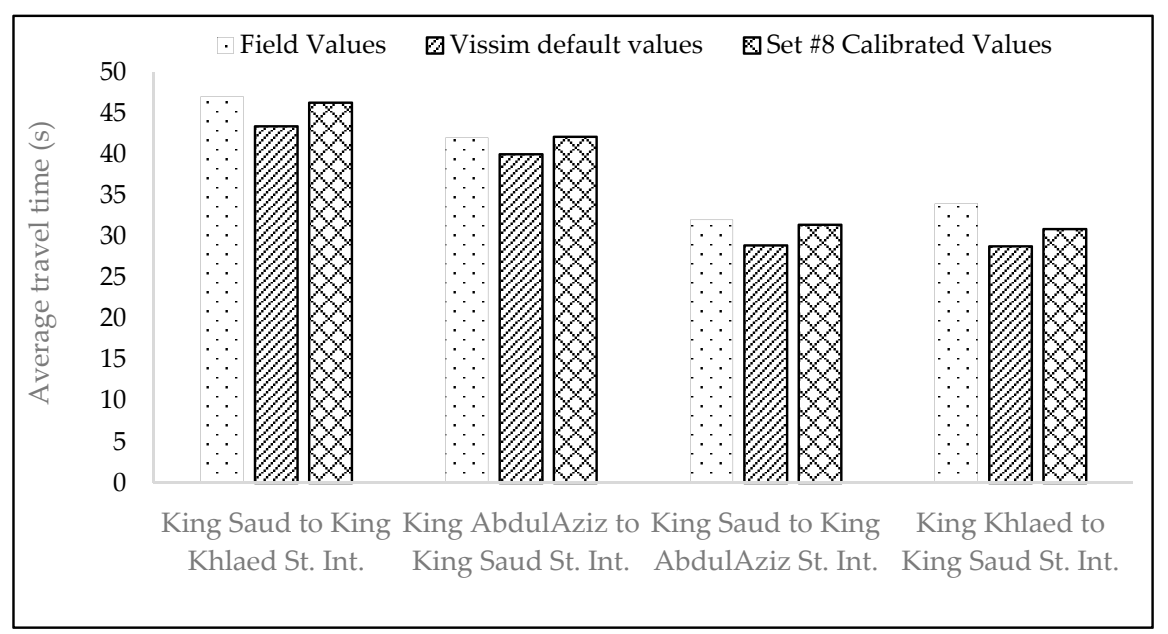

(b) Travel time comparison.

Figure 4. Comparison of average travel time and average link speed from field and calibrated VISSIM parameters for validation analysis. 


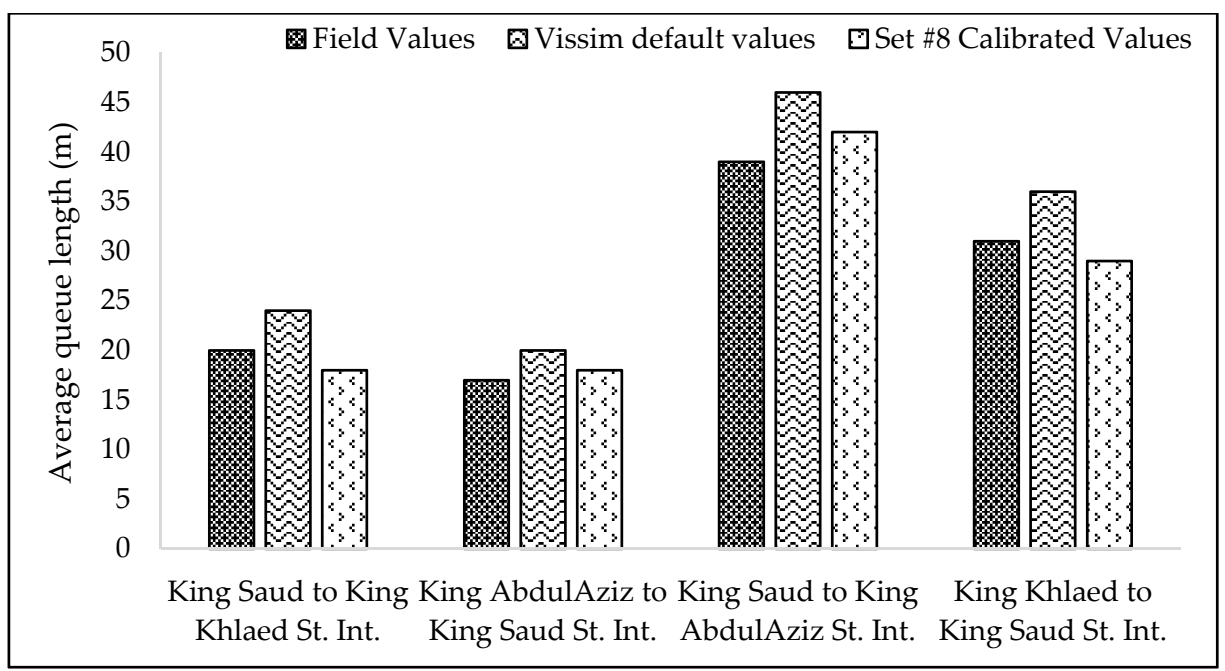

(a) Average queue length comparison.

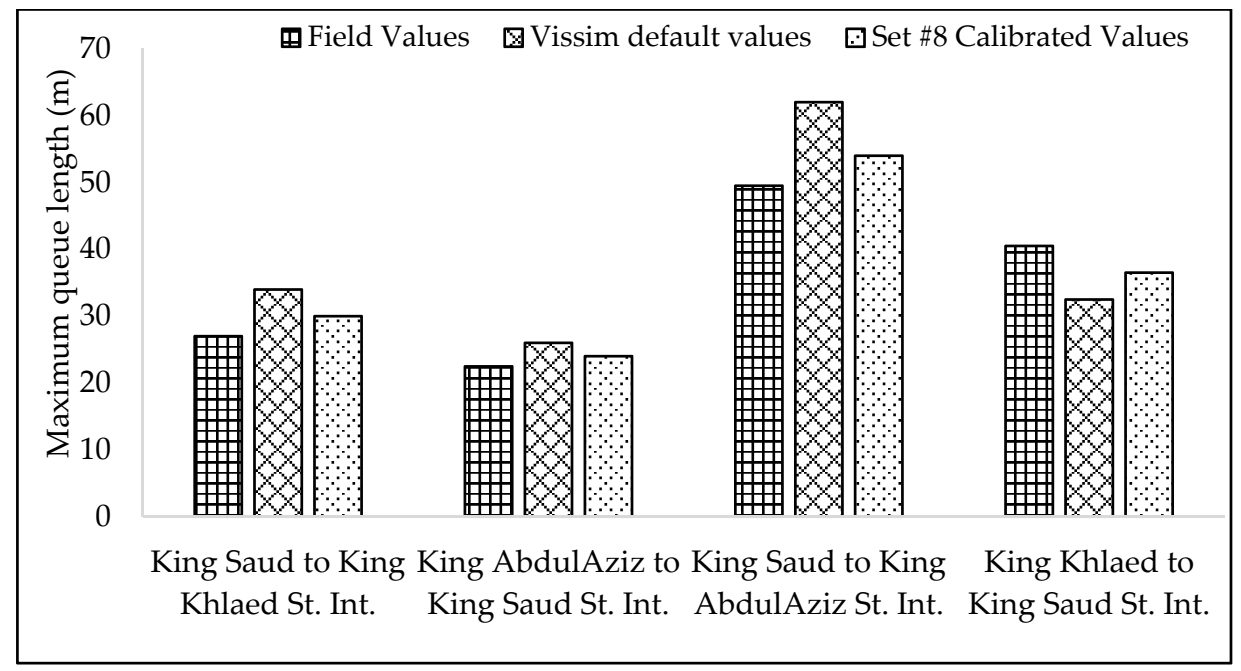

(b) Maximum queue length comparison.

Figure 5. Comparison of average and maximum queue length from field and calibrated VISSIM parameters for validation analysis.

A comparison of field data, MOEs obtained from VISSIM with default values of parameters (uncalibrated parameters), and those obtained with calibrated parameters, proved the importance of calibration and validation. As shown above in Tables 5-8, and Figures 4 and 5, the calibrated models replicated the field data better than uncalibrated models. The uncalibrated models on average indicated higher link speed, larger queue lengths, and shorter travel times compared to those observed from the field. For the average link speed, the change with respect to the field-measured value was between $19-25 \%$ and $2-5 \%$ when the default value and calibrated parameter values were used, respectively, as shown in Table 9. For the travel time, the range of change was between $4-15 \%$ for the default value and $0.2-9 \%$ when calibrated parameters were used. For the travel time, the King Khaled Street to King Saud Street approach had the maximum of a 9\% difference among all of the approaches, while the minimum difference was only $0.3 \%$ for the King Abdul-Aziz Street to King Saud Street approach. While comparing the average speed and travel time for different approaches, it was observed that the positive difference of average speed is always associated with a decline in travel time for most of the cases. Average and maximum queue length was also comparable and accounted for $6-9 \%$ difference to the field observation. Therefore, all compared MOEs used to validate the model matched within 
a range of $5-10 \%$ to the field-observed values. This shows the insight of the appropriateness of the model calibration with the selected parameters for this particular network.

Table 9. Percentage difference in MOEs.

\begin{tabular}{ccccccccc}
\hline \multirow{2}{*}{ Street Name } & \multicolumn{2}{c}{$\begin{array}{c}\text { Percentage Difference in } \\
\text { Average Aped (kmph) }\end{array}$} & \multicolumn{2}{c}{$\begin{array}{c}\text { Percentage Difference in } \\
\text { Travel Time (sec) }\end{array}$} & $\begin{array}{c}\text { Percentage Difference in } \\
\text { Average Queue (m) }\end{array}$ & $\begin{array}{c}\text { Percentage Difference in } \\
\text { Maximum Queue (m) }\end{array}$ \\
\cline { 2 - 10 } & $\begin{array}{c}\text { VISSIM } \\
\text { Default }\end{array}$ & Set \#8 & $\begin{array}{c}\text { VISSIM } \\
\text { Default }\end{array}$ & Set \#8 & $\begin{array}{c}\text { VISSIM } \\
\text { Default }\end{array}$ & Set \#8 & $\begin{array}{c}\text { VISSIM } \\
\text { Default }\end{array}$ & Set \#8 \\
\hline $\begin{array}{c}\text { King Saud to King } \\
\text { Khaled St. Int. }\end{array}$ & 19.31 & 4.90 & -7.66 & -1.55 & 20.00 & -8.80 & 25.93 & 9.67 \\
$\begin{array}{c}\text { King Abdul-Aziz to } \\
\text { King Saud St. Int. }\end{array}$ & -8.48 & -2.73 & -4.76 & 0.29 & 17.65 & 5.88 & 15.56 & 6.67 \\
$\begin{array}{c}\text { King Saud to King } \\
\text { Abdul-Aziz St. Int. }\end{array}$ & 12.00 & 4.72 & -9.69 & -1.81 & 17.95 & 7.69 & 25.25 & 9.09 \\
$\begin{array}{c}\text { King Khaled to King } \\
\text { Saud St. Int. }\end{array}$ & 24.69 & -3.31 & -15.29 & -9.12 & 16.13 & -6.45 & -19.75 & -9.88 \\
\hline
\end{tabular}

\subsection{Comparison of Calibrated Driving Behavior Parameters}

As driving behavior is highly influenced by social and cultural background and geographical location, it might be useful to draw a comparison of driving behavior parameters with past studies conducted in different parts of the world. As the Kingdom of Saudi Arabia is home to many expatriates, mostly from different parts of Asia and other countries, along with the Saudi citizens, there might be differences in driving behavior among the driver groups with disparate backgrounds. A table (Table 10) showing a comparison of driving behavior parameters with other studies indicates that the drivers in Saudi Arabia are more on the conservative side.

Table 10. Comparison of driving behavior parameters with other studies.

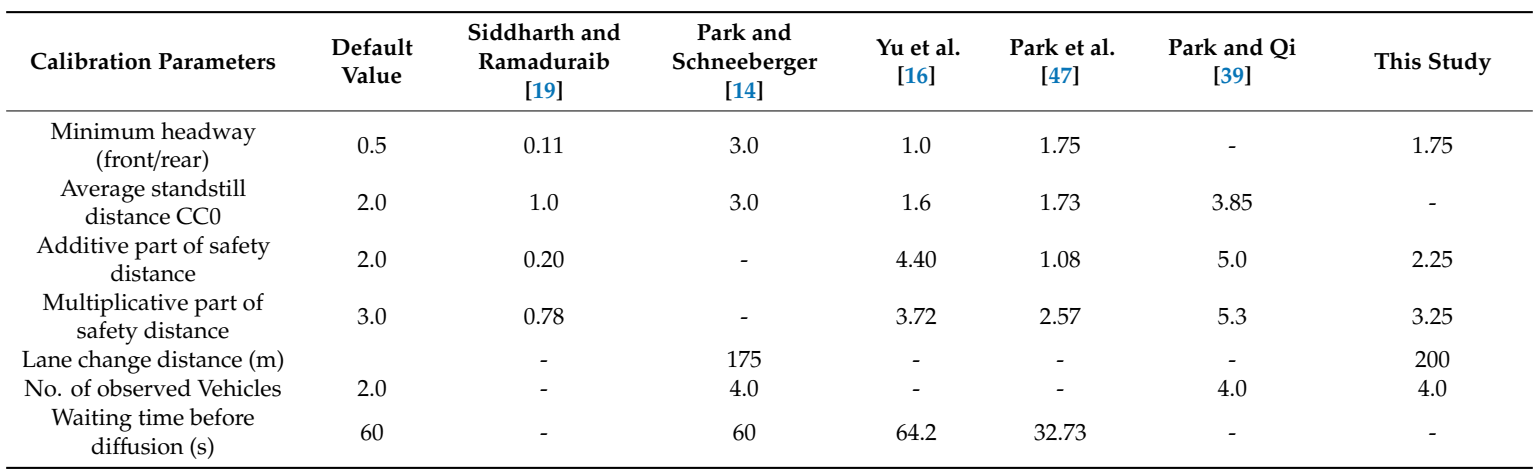

\section{Conclusions}

A calibration and validation of microscopic simulation models was demonstrated through a case study for the Khobar-Dammam metropolitan areas in order to find the optimal value of microscopic driving behavior parameters. The proposed methodology adopted for calibration and validation for VISSIM software was found effective for the signalized intersections, considered for this study. It was concluded the VISSIM microsimulation model with default parameter values is incapable of replicating the field conditions, while parameter calibration can enhance the precision of MOEs considerably. The uncalibrated models on average indicate higher link speed, larger queue lengths, and shorter travel times than those observed from the field. The validation results of calibrated parameters for traffic conditions on Prince Mohammad bin Fahd Road demonstrated the adequacy of these calibrated parameters. The validation of the calibrated model network was performed with data from a different day, however, it might be desirable to validate the network under a different control setting (e.g., with different posted speed limits). Through the process of calibration and validation for the road network, this study was able to identify some important driving behavioral parameters that can be used later as benchmarks for other studies to simulate different scenarios in VISSIM prior to 
their field implementation. Future research can potentially utilize this information to find a link to the possible causes of road crashes using the driver behavior data. Findings from the present study can guide policy makers and concerned parties on efficient use of limited resources, and thus the goal of long-term sustainable development in the areas can be ensured.

\section{Study Limitations and Recommendations}

The study used three performance measures and a single day's data. If possible, collecting field data on multiple days is recommended, as is considering more variability in field data. Further calibration could be carried at the corridor and network level to determine whether the calibration process and parameters calibrated are adequate for replicating other regional networks or are only applicable to these specific intersections. A range of geometries and flow conditions would result in more general conclusions. For modelling traffic conditions under the varying infrastructure prevalent in the Kingdom of Saudi Arabia, the present study can be further expanded in future by taking in to account a more comprehensive set of calibration parameters.

Author Contributions: H.M.A.-A. designed the research methodology and reviewed the manuscript, A.J. wrote Section 3, Section 5, and Section 7, and edited the entire manuscript. I.R. wrote Section 1 and conducted VISSIM simulations. K.J.A. wrote Sections 8-10 and A.A. supervised field data collection and wrote Sections 4 and 6.

Funding: This research received no external funding.

Acknowledgments: The authors appreciate and acknowledge the support of KFUPM.

Conflicts of Interest: The authors declare no conflict of interest.

\section{References}

1. Giuffrè, T.; Trubia, S.; Canale, A.; Persaud, B. Using microsimulation to evaluate safety and operational implications of newer roundabout layouts for European Road networks. Sustainability 2017, 9, 2084. [CrossRef]

2. Young, W.; Sobhani, A.; Lenné, M.G.; Sarvi, M. Simulation of safety: A review of the state of the art in road safety simulation modelling. Accid. Anal. Prev. 2014, 66, 89-103. [CrossRef] [PubMed]

3. Chen, C.; Zhao, X.; Liu, H.; Ren, G.; Zhang, Y.; Liu, X. Assessing the Influence of Adverse Weather on Traffic Flow Characteristics Using a Driving Simulator and VISSIM. Sustainability 2019, 11, 830. [CrossRef]

4. Astarita, V.; Giofré, V.; Guido, G.; Vitale, A. Calibration of a new microsimulation package for the evaluation of traffic safety performances. Procedia-Soc. Behav. Sci. 2012, 54, 1019-1026. [CrossRef]

5. Mahmud, S.S.; Ferreira, L.; Hoque, M.S.; Tavassoli, A. Micro-simulation modelling for traffic safety: A review and potential application to heterogeneous traffic environment. IATSS Res. 2018, 43, 27-36. [CrossRef]

6. Lu, Z.; Fu, T.; Fu, L.; Shiravi, S.; Jiang, C. A video-based approach to calibrating car-following parameters in VISSIM for urban traffic. Int. J. Transp. Sci. Technol. 2016, 5, 1-9. [CrossRef]

7. Espejel-Garcia, D.; Saniger-Alba, J.A.; Wenglas-Lara, G.; Espejel-Garcia, V.V.; Villalobos-Aragon, A. A Comparison among Manual and Automatic Calibration Methods in VISSIM in an Expressway (Chihuahua, Mexico). Open J. Civ. Eng. 2017, 7, 539-552. [CrossRef]

8. Fellendorf, M.; Vortisch, P. Fundamentals of Traffic Simulation; Springer: New York, NY, USA, 2010; Volume 145.

9. Henclewood, D.; Suh, W.; Rodgers, M.O.; Fujimoto, R.; Hunter, M.P. A calibration procedure for increasing the accuracy of microscopic traffic simulation models. Simulation 2017, 93, 35-47. [CrossRef]

10. Manjunatha, P.; Vortisch, P.; Mathew, T. Methodology for the Calibration of VISSIM in Mixed Traffic. Transportation Research Board 92nd Annual Meeting. 2013. Available online: http://docs.trb.org/prp/133677.pdf (accessed on 12 March 2019).

11. Mehar, A.; Chandra, S.; Velmurugan, S. Highway capacity through vissim calibrated for mixed traffic conditions. KSCE J. Civ. Eng. 2014, 18, 639-645. [CrossRef]

12. Park, B.; Schneeberger, J.D. Microscopic simulation model calibration and validation: Case study of VISSIM simulation model for a coordinated actuated signal system. Transp. Res. Rec. 2003, 1856, 185-192. [CrossRef]

13. Song, R.; Sun, J. Calibration of a micro-traffic simulation model with respect to the spatial-temporal evolution of expressway on-ramp bottlenecks. Simulation 2016, 92, 535-546. [CrossRef] 
14. Srikanth, S.; Mehar, A.; Parihar, A. Calibration of Vissim Model for Multilane Highways Using Speed Flow Curves. Stavební Obz. Civ. Eng. J. 2017, 26, 303-314. [CrossRef]

15. Bonsall, P.; Liu, R.; Young, W. Modelling safety-related driving behaviour-impact of parameter values. Transp. Res. Part A Policy Pract. 2005, 39, 425-444. [CrossRef]

16. Yu, M.; Fan, W.D. Calibration of microscopic traffic simulation models using metaheuristic algorithms. Int. J. Transp. Sci. Technol. 2017, 6, 63-77. [CrossRef]

17. Jing, D.; Andrew, H.; Navid, S.; Chaoru, L.; Neal, H. VISSIM Calibration for Urban Freeways ISU Non-Discrimination Statement Iowa DOT Statements; Iowa State University: Ames, IA, USA, 2015.

18. Sacks, J.; Rouphail, N.; Park, B.; Thakuriah, P. Statistically-based validation of computer simulation models in traffic operations and management. J. Transp. Stat. 2002, 5, 1-24. Available online: http://www.academia. edu/download/30900159/JTSStatisticalCORSIMWithDiscussion.pdf (accessed on 19 February 2019).

19. Siddharth, S.P.; Ramadurai, G. Calibration of VISSIM for Indian heterogeneous traffic conditions. Procedia-Soc. Behav. Sci. 2013, 104, 380-389. [CrossRef]

20. Mathew, T.V.; Radhakrishnan, P. Calibration of microsimulation models for nonlane-based heterogeneous traffic at signalized intersections. J. Urban Plan. Dev. 2010, 136, 59-66. [CrossRef]

21. Nomani Kabir, M.; Alginahi, Y.M.; Mohamed, A.I. Modeling and Simulation of Traffic Flow: A Case-First Ring Road in Downtown Madinah. Int. J. Softw. Eng. Comput. Syst. (IJSECS) 2016, 2289-8522. [CrossRef]

22. Ratrout, N.T.; Rahman, S.M.; Reza, I. Calibration of PARAMICS Model: Application of Artificial Intelligence-Based Approach. Arab. J. Sci. Eng. 2015, 40, 3459-3468. [CrossRef]

23. Reza, I.; Ratrout, N.; Rahman, S.M. Calibration protocol for PARAMICS microscopic traffic simulation model: Application of neuro-fuzzy approach. Can. J. Civ. Eng. 2007, 43, 361-368. [CrossRef]

24. Yang, Y.; Qin, Y.; Dong, H.; Zhang, Q. Parameter Calibration Method of Microscopic Traffic Flow Simulation Models based on Orthogonal Genetic Algorithm. In Proceedings of the 22nd International Conference on Distributed Multimedia Systems, Salerno, Italy, 25-26 November 2016; pp. 55-60. [CrossRef]

25. Menneni, S.; Sun, C.; Vortisch, P. Microsimulation calibration using speed-flow relationships. Transp. Res. Rec. 2008, 2088, 1-9. [CrossRef]

26. Wiedemann, R. Simulation des Strassenverkehrsflusses; Schriftenreihe des Instituts für Verkehrswesen der Universität Karlsruhe: Karlsruhe, Germany, 1974.

27. Wiedemann, R. Modelling of RTI-Elements on multi-lane roads. In Advanced Telematics in Road Transport, Proceedings of the DRIVE Conference. Volume II; Elsevier: New York, NY, USA, 1991.

28. Shaaban, K.; Kim, I. Comparison of SimTraffic and VISSIM microscopic traffic simulation tools in modeling roundabouts. Procedia Comput. Sci. 2015, 52, 43-50. [CrossRef]

29. Uludamar, E.; Tuccar, G. Comparison of Traffic Densities at Different Signalization Timings in Roundabouts. J. Eng. Sci. 2018, 7, 217-223. [CrossRef]

30. Ciuffo, B.; Punzo, V.; Torrieri, V. Comparison of simulation-based and model-based calibrations of traffic-flow microsimulation models. Transp. Res. Rec. 2008, 2088, 36-44. [CrossRef]

31. Ma, J.; Dong, H.; Zhang, H.M. Calibration of microsimulation with heuristic optimization methods. Transp. Res. Rec. 2007, 1999, 208-217. [CrossRef]

32. Hourdakis, J.; Michalopoulos, P.G.; Kottommannil, J. Practical procedure for calibrating microscopic traffic simulation models. Transp. Res. Rec. 2003, 1852, 130-139. [CrossRef]

33. Lee, J.B.; Ozbay, K. New calibration methodology for microscopic traffic simulation using enhanced simultaneous perturbation stochastic approximation approach. Transp. Res. Rec. 2009, 2124, 233-240. [CrossRef]

34. Balakrishna, R.; Antoniou, C.; Ben-Akiva, M.; Koutsopoulos, H.N.; Wen, Y. Calibration of microscopic traffic simulation models: Methods and application. Transp. Res. Rec. 2007, 1999, 198-207. [CrossRef]

35. Abdalhaq, B.K.; Baker, M.I. Using meta heuristic algorithm to improve traffic simulation. J. Algorithm Optim. 2014, 2, 110-128.

36. Kim, S.J.; Kim, W.; Rilett, L.R. Calibration of microsimulation models using nonparametric statistical techniques. Transp. Res. Rec. 2005, 1935, 111-119. [CrossRef]

37. Asamer, J.; van Zuylen, H.J.; Heilmann, B. Calibrating VISSIM to adverse weather conditions. In Proceedings of the 2nd International Conference on Models and Technologies for Intelligent Transportation Systems, Leuven, Belgium, 22-24 June 2011; Volume 22, p. 24. 
38. Zhizhou, W.; Jian, S.; Xiaoguang, Y. Calibration of VISSIM for shanghai expressway using genetic algorithm. In Proceedings of the IEEE Winter Simulation Conference, Orlando, FL, USA, 4 December 2005; p. 4.

39. Park, B.; Qi, H. Development and Evaluation of a Procedure for the Calibration of Simulation Models. Transp. Res. Rec. J. Transp. Res. Board 2005, 208-217. [CrossRef]

40. Punzo, V.; Ciuffo, B. How parameters of microscopic traffic flow models relate to traffic conditions and implications on model calibration. Transp. Res. Rec. J. Transp. Res. Board 2009, 2124, 249-256. [CrossRef]

41. Ge, Q.; Menendez, M. Sensitivity Analysis for Calibrating VISSIM in Modeling the Zurich Network. In Proceedings of the 12th Swiss Transport Research Conference, Ascona, Switzerland, 2-4 May 2012.

42. Chu, L.; Liu, H.X.; Oh, J.S.; Recker, W. A calibration procedure for microscopic traffic simulation. In Proceedings of the 2003 IEEE International Conference on Intelligent Transportation Systems, Shanghai, China, 12-15 October 2003; Volume 2, pp. 1574-1579. [CrossRef]

43. Oregon Department of Transportation. Protocol for VISSIM Simulation; Oregon Department of Transportation: Salem, OR, USA, 2011.

44. Washington State Department of Transportation. Protocol for VISSIM Simulation; Washington State Department of Transportation: Olympia, WA, USA, 2014.

45. Maryland Department of Transportation. VISSIM Modeling Guidance; Maryland Department of Transportation: Hanover, MD, USA, 2017.

46. Fred, C.; Milam, R.T.; David, S. CORSIM, PARAMICS, and VISSIM: What the Manuals Never Told You. In Proceedings of the Ninth TRB Conference on the Application of Transportation Planning Methods, Baton Rouge, LA, USA, 6-10 April 2003.

47. Park, B.; Won, J.; Yun, I. Application of microscopic simulation model calibration and validation procedure: Case study of coordinated actuated signal system. Transp. Res. Rec. 2006, 1978, 113-122. [CrossRef]

(C) 2019 by the authors. Licensee MDPI, Basel, Switzerland. This article is an open access article distributed under the terms and conditions of the Creative Commons Attribution (CC BY) license (http://creativecommons.org/licenses/by/4.0/). 